\title{
Determination of Some Physicochemical Parameters and Some Heavy Metals in Boreholes from Fagge L.G.A of Kano Metropholis Kano State- Nigeria
}

\author{
SA'EED M.D*, MAHMOUD A.M \\ DEPERTMENT OF CHEMISTRY PURE AND INDUSTRIAL CHEMISTRY BAYERO UNIVERSITY KANO STATE- NIGERIA \\ *Corresponding author: ashirk9@yahoo.com
}

Received September 09, 2014; Revised October 25, 2014; Accepted December 09, 2014

\begin{abstract}
There are some settlements in Fagge L.G.A of Kano metropolis that are located along Jakara river and thus there's the fear that the drinking water they consume could be hazardous, as such, there's a need for a study to be carried out to assess the levels of some physicochemical parameters and some heavy metals in borehole water that is meant for drinking and domestic purposes. Thirty water samples were randomly collected from different sampling sites and were analyzed using standard methods of analysis. The results showed that $\mathrm{pH}$ had a mean level of 7.26 \pm 0.43 , Conductivity mean level was $856.1 \pm 388.6 \mu \mathrm{Scm}^{-1}$, the mean total hardness was $295.9 \pm 137.2 \mathrm{mg} / \mathrm{l}$, turbidity had a mean level of $0.98 \pm 0.73$ NTU, the total dissolved Solid TDS mean levels was 509.4 $\pm 200.9 \mathrm{mg} / \mathrm{l}$. The heavy metals analyzed include Lead, Cadmium, and Chromium using Buck scientific model 210 VGP atomic absorption spectrometer and they had mean levels of $0.103 \pm 0.07,0.012 \pm 0.03$ and $0.065 \pm 0.095$ respectively. As the results indicated all the physicochemical parameters and heavy metals are within the maximum contaminant levels set by WHO, 2005. Except for $\mathrm{pH}$ level in Weather head and Lead level in Kwarin Gogau sampling sites respectively. The statistical analysis of Anova showed that there is a significant difference between the physicochemical parameters and heavy metals analyzed as probability factor $\mathrm{p}<0.05$.
\end{abstract}

Keywords: physicochemical parameters, heavy metals, borehole, water samples, Fagge L.G.A Kano metropolis

Cite This Article: SA'EED M.D, and MAHMOUD A.M, "Determination of Some Physicochemical Parameters and Some Heavy Metals in Boreholes from Fagge L.G.A of Kano Metropholis Kano State- Nigeria.” World Journal of Analytical Chemistry, vol. 2, no. 2 (2014): 42-46. doi: 10.12691/wjac-2-2-4.

\section{Introduction}

Water is one of the most valuable natural resources and is essential for the maintenance of all forms of life [4]. [1] reported that, the importance of water in our daily lives is what makes it imperative for thorough analysis to be conducted, the analysis is the concern of the chemist to ensure that supply of water is safe for all purposes and to ensure that only water with good qualities are used for both domestic and industrial uses.

[9] Observed that the rate of discharge of pollutants into the environments, which ultimately find their way into the water bodies is higher than the rate of purification. This could be due to rapid urbanization, industrialization and growing population. Water pollution is a major global problem which requires ongoing evaluation and revision of water resource policy at all levels [7]. It has been suggested that it is the leading worldwide cause of deaths and diseases and that it accounts for the deaths of more than 14,000 people daily [7]. It has been estimated that 580 people in India die of water pollution related illness every day. [13].

In addition to the acute problems of water pollution in developing countries, developed countries continue to struggle with pollution problems as well. A report from China's national development agency in 2007 said that, 1/4th the length of China's seven main rivers were so poisoned the water harmed the skin [13].

\section{Material and Method}

In the preparation of reagents chemicals of analytical Analar grade were used with deionised water. All glass ware were cleaned and rinsed with detergents and immersed in $25 \%$ nitric acid and finally rinsed with de ionized water.

\subsection{Sampling}

Thirty samples of borehole water were collected from different areas of Fagge local Government of Kano State in triplicate using clean new polyethene plastic containers which were covered with Black polyethene bags to prevent growth of Algae. The $\mathrm{pH}$ and conductivity, ware determined immediately after sampling and the sample was stored at a temperature below $4^{\circ} \mathrm{C}$, this is to prevent the growth of microorganisms. However, the sampling was conducted between $23^{\text {rd }}-26^{\text {th }}$ December, 2013. 


\subsection{Study Area}

Fagge is a local government area in Kano state Nigeria, within the greater Kano Area, its headquarter is in the
Suburb of Waje. It has an Area of $21 \mathrm{~km}$ and a population of 198,828 at the 2006 census. In Nigerian map, it is located in $1224^{\circ} \mathrm{N}, 831^{\circ} \mathrm{E}$ with 3 digit postal code prefix 700 [8].

Table 1. The sampling sites and their ID

\begin{tabular}{|c|c|c|c|c|}
\hline S/N & SAMPLING SITES & ID code & S/N & SAMPLING SITES \\
\hline 1 & Garba A.D Street & A & 16 & Abba Gana Street \\
\hline 2 & Titinbo Street & B & 17 & Dan Wawu Street \\
\hline 3 & Kwalta Street & C & 18 & Galadima Road \\
\hline 4 & Kwarin Gogau & $\mathrm{D}$ & 19 & Abacha Street, Sabon Gari \\
\hline 5 & Samaru Fagge & $\mathrm{E}$ & 20 & Fagge South \\
\hline 6 & Kwari Market & $\mathrm{F}$ & 21 & Niger Road \\
\hline 7 & Yan Babura & $\mathrm{G}$ & 22 & Singer Market, S/Gari \\
\hline 8 & Dingazimi Street & $\mathrm{H}$ & 23 & Weather Head, S/Gari \\
\hline 9 & Salam Opp. Triumph & $\mathrm{I}$ & 24 & Festing Road, S/Gari \\
\hline 10 & Mutari Atamma Street & $\mathrm{J}$ & 25 & Abeokuta Road, S/gari \\
\hline 11 & Triump Juma'at Mosque & $\mathrm{K}$ & 26 & Atiken Road, S/Gari \\
\hline 12 & Haido Islamiyya & $\mathrm{L}$ & 27 & S \\
\hline 13 & Fagge Model Primary Sch. & $\mathrm{M}$ & 28 & Y Giwa Road, S/gari \\
\hline 14 & Ammani Inuwa Street & $\mathrm{N}$ & 29 & Z \\
\hline 15 & Alh. Mudi Street & $\mathrm{O}$ & 30 & Amire Road, S/Gari \\
\hline
\end{tabular}

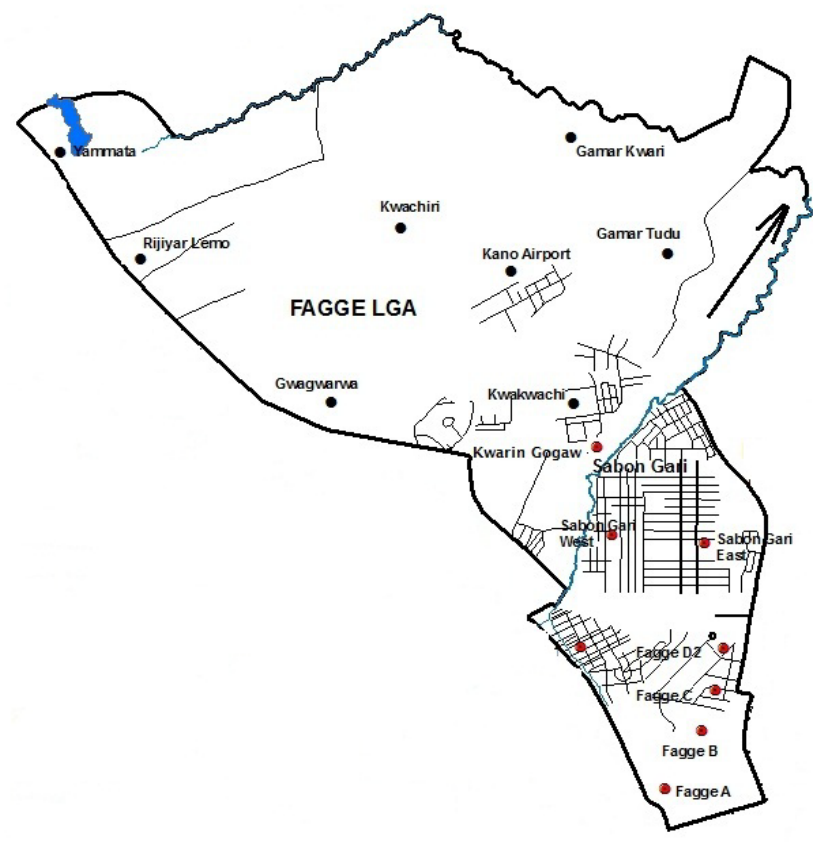

Figure 1. Showing the Sampling Sites

\section{Methodology}

\section{1. pH Measurement}

The $\mathrm{pH}$ was measured using a digital $\mathrm{pH}$ meter (HARCH SENS ION). The meter was switched on and was allowed to warm for 5 minutes. It was then standardized with a buffer solution. The meter was then immediately introduced into the water sample and measurement was taking after a stable reading was taken. The electrode was then rinsed with deionized water before taken another measurement [2].

\subsection{Conductivity Measurement}

Conductivities of the water samples were measured using a digital conductivity meter (HARCH Model). The meter was switched on and then standardized using $0.1 \mathrm{~N}$
$\mathrm{KCl}$ at $25^{\circ} \mathrm{C}$. The electrode was then immersed into the water sample and conductivity reading of each sample was recorded [12].

\subsection{Turbidity Measurement}

The turbidities of the water samples were measured using a digital turbidity meter (2100AN HARCH Model). The meter was standardized with a clean deionized water, and this was introduce into the water samples. The turbidity reading of each sample was then recorded [6].

\subsection{Determination of Total Dissolved Solid}

The total dissolved solid was determined using a Conductivity meter, the programme menu of the Conductivity meter was switched to total dissolved solid, $100 \mathrm{~cm}^{3}$ of the sample was measured into the beaker and the electrode was introduced into the sample. The results of total dissolved solid were displayed and recorded [2]. Similarly, gravimetric method was also used to determine the Total Dissolved Solid by evaporation in an oven at $200^{\circ} \mathrm{C}$ for 2 hrs. This is to ascertain the accuracy of the above mentioned method by comparing the two results no significant difference was recorded only that it has more time consuming as reported by [3].

\subsection{Determination of Total Hardness}

$10 \mathrm{~cm}^{3}$ of water sample was pipetted into a conical flask. $1 \mathrm{~cm}^{3}$ of buffer solution $\left(\mathrm{NH}_{4} \mathrm{Cl}\right)$ of $\mathrm{pH}=10$ and 3 drops of Erichrome black $\mathrm{T}$ indicator were added to the flask. The mixture was then titrated with 0.0IM EDTA (ethyl diammine tetra acetic acid) until the color changed from wine red to blue.The procedure was repeated two more times to obtain the average litre value [1].

\subsection{Determination of Alkalinity}

Procedure: $100 \mathrm{~cm}^{3}$ of Sample was taken followed by 2-3 drops of phenolphthalein indicator and the color change was observed followed by titrating with $0.1 \mathrm{~N} \mathrm{HCl}$ until the color changed from pink to colorless [4] 


\section{Results and Discussion}

People are increasingly concerned about the safety of their water, as of now the main source of our drinking water in urban and rural areas is mainly boreholes. Current improvements of analytical methods which allow for the detection of impurities even at lower concentrations make it easier to ascertain the quality of the water we drink.

The results of some physicochemical parameters and some heavy metals analyzed in borehole drinking water samples from some sampling sites across Fagge L.G.A. of Kano metropolis are presented in tables $1,2,3$, and 4 respectively:

Table 2. The Mean levels of pH, conductivity and Total Dissolved Solid, Sodium and Potassiumof the water samples

\begin{tabular}{|c|c|c|c|c|c|c|}
\hline $\mathrm{S} / \mathrm{N}$ & SAMPLES & $\mathrm{pH}$ & CONDUCTIVITY $(\mu \mathrm{S} / \mathrm{cm})$ & TDS $\left(\mathrm{mgl}^{-1}\right)$ & $\mathrm{Na}\left(\mathrm{mgl}^{-1}\right)$ & $\mathrm{K}\left(\mathrm{mgl}^{-1}\right)$ \\
\hline 1 & Garba A.D Street & $7.6 \pm 0.13$ & $1280 \pm 12.1$ & $729.6 \pm 12.1$ & $1.9 \pm 0.1$ & $0.3 \pm 0.0$ \\
\hline 2 & Titinbo Street & $7.2 \pm 0.15$ & $767 \pm 16.5$ & $475 . \pm 15.4$ & $2.6 \pm 0.2$ & $6.2 \pm 0.2$ \\
\hline 3 & Kwalta Street & $8.2 \pm 0.24$ & $865 \pm 14.2$ & $682 \pm 12.5$ & $0.6 \pm 0.0$ & $1.4 \pm 0.5$ \\
\hline 4 & Kwarin Gogau & $7.9 \pm 0.22$ & $593 \pm 12.9$ & $367.66 \pm 1.0$ & $4.8 \pm 0.4$ & $1.0 \pm 0.0$ \\
\hline 5 & Samaru & $7.1 \pm 0.11$ & $860 \pm 12.7$ & $498.8 \pm 1.0$ & $8.2 \pm 0.2$ & $2.0 \pm 0.0$ \\
\hline 6 & Kwari Market & $7.4 \pm 0.14$ & $1101 \pm 14.7$ & $748.68 \pm 33.5$ & $4.9 \pm 0.2$ & $0.2 \pm 0.1$ \\
\hline 7 & Yan Babura & $7.6 \pm 0.12$ & $540 \pm 21.9$ & $329.4 \pm 21.4$ & $4.2 \pm 0.1$ & $3.9 \pm 0.1$ \\
\hline 8 & Dingazimi Street & $7.1 \pm 0.31$ & $1450 \pm 31.2$ & $832.6 \pm 1.3$ & $2.0 \pm 0.1$ & $6.4 \pm 0.8$ \\
\hline 9 & Salam Opp. Triump & $8.0 \pm 0.21$ & $1270 \pm 41.6$ & $624.1 \pm 2.1$ & $2.6 \pm 0.3$ & $5.9 \pm 1.3$ \\
\hline 10 & Mutari Atamma Street & $7.6 \pm 0.34$ & $1250 \pm 21.1$ & $877.4 \pm 4.3$ & $0.7 \pm 0.0$ & $3.9 \pm 0.3$ \\
\hline 11 & Triump Juma'at Mosque & $7.2 \pm 010$ & $1700 \pm 31.1$ & $677.5 \pm 19.3$ & $1.2 \pm .01$ & $6 . .6 \pm 0.0$ \\
\hline 12 & Haido Islamiyya & $6.8 \pm 0.14$ & $750 \pm 41.2$ & $501.3 \pm 2.6$ & $2.8 \pm 0.2$ & $5.2 \pm 0.4$ \\
\hline 13 & Fagge Model Primary Sch. & $7.3 \pm 0.23$ & $556 \pm 21.3$ & $420.5 \pm 21.5$ & $7.1 \pm 0.3$ & $3.5 \pm 1.0$ \\
\hline 14 & Ammani Inuwa Street & $7.5 \pm 0.11$ & $630 \pm 41.6$ & $362.64 \pm 23.5$ & $3.0 \pm 0.6$ & $0.8 \pm 0.0$ \\
\hline 15 & Alh. Mudi Street & $7.2 \pm 0.24$ & $1234 \pm 31.2$ & $653.1 \pm 53.4$ & $1.0 \pm 0.0$ & $3.8 \pm 0.5$ \\
\hline 16 & Abba Gana Street & $7.0 \pm 0.14$ & $543 \pm 21.0$ & $418.5 \pm 45.3$ & $1.4 \pm 0.1$ & $4.6 \pm 0.7$ \\
\hline 17 & Dan Wawu Street & $6.8 \pm 0.18$ & $567 \pm 11.2$ & $320 \pm 53.2$ & $5.8 \pm 1.0$ & $6.6 \pm 0.6$ \\
\hline 18 & Galadima Road & $7.5 \pm 0.22$ & $431 \pm 31.2$ & $284.1 \pm 41.2$ & $10.6 \pm 2.2$ & $1.9 \pm 0.5$ \\
\hline 19 & Abacha Line Sabon Gari & $7.3 \pm 0.13$ & $532 \pm 41.2$ & $322.3 \pm 53.2$ & $2.0 \pm 0.1$ & $0.2 \pm 0.3$ \\
\hline 20 & Fagge South & $7.6 \pm 0.15$ & $421 \pm 51.2$ & $313.1 \pm 44.3$ & $11.2 \pm 1.6$ & $6.7 \pm 0.2$ \\
\hline 21 & Niger Road & $6.9 \pm 0.31$ & $678 \pm 21.4$ & $377 \pm 12.5$ & $1.0 \pm 0.1$ & $4.8 \pm 0.4$ \\
\hline 22 & Singer Market S/Gari & $7.1 \pm 0.11$ & $1321 \pm 13.4$ & $876.8 \pm 21.4$ & $3.1 \pm 0.18$ & $4.6 \pm 0.6$ \\
\hline 23 & Weather head S/Gari & $6.2 \pm 0.14$ & $345 \pm 21.1$ & $237.2 \pm 11.5$ & $5.5 \pm 0.3$ & $6.2 \pm 1.3$ \\
\hline 24 & Festing Road S/Gari & $6.5 \pm 0.17$ & $542 \pm 21.3$ & $401.4 \pm 19.8$ & $5.5 \pm 0.4$ & $6.2 \pm 1.4$ \\
\hline 25 & Abeokuta Road S/gari & $6.8 \pm 0.43$ & $654 \pm 13.5$ & $376.9 \pm 21.4$ & $4.8 \pm 0.2$ & $5.4 \pm 0.1$ \\
\hline 26 & Atiken Road S/Gari & $7.5 \pm 0.21$ & $1324 \pm 14.6$ & $691.6 \pm 24.3$ & $1.5 \pm 0.3$ & $5.6 \pm 0.7$ \\
\hline 27 & Sani giwa Road S/gari & $7.7 \pm 0.42$ & $346 \pm 11.9$ & $220.5 \pm 13.4$ & $0.9 \pm 0.5$ & $4.9 \pm 0.4$ \\
\hline 28 & Abedie Street S/Gari & $7.3 \pm 0.16$ & $1234 \pm 41.5$ & $661.4 \pm 32.1$ & $4.2 \pm 0.6$ & $0.6 \pm 0.5$ \\
\hline 29 & Amire Road S/Gari & $6.9 \pm 0.23$ & $543 \pm 14.6$ & $293.5 \pm 34.5$ & $6.0 \pm 1.6$ & $2.9 \pm 0.1$ \\
\hline 30 & Sarkin Yaki Road S/Gari & $7.1 \pm 0.11$ & $1356 \pm 13.2$ & $707.6 \pm 21.3$ & $0.5 \pm 0.2$ & $4.9 \pm 0.1$ \\
\hline
\end{tabular}

Table 3. Mean Levels of Total Hardness, Alkalinity, and turbidity of the water samples

\begin{tabular}{|c|c|c|c|c|}
\hline $\mathrm{S} / \mathrm{N}$ & SAMPLES & TOTAL HARDNESS (mgl-1) & ALKALINITY (mgl-1) & TURBIDITY (NTU) \\
\hline 1 & Garba A.D Street & $430.5 \pm 3.67$ & $560 \pm 12.1$ & $0.57 \pm 0.02$ \\
\hline 2 & Titinbo Street & $580.2 \pm 10.5$ & $414 \pm 12.9$ & $0.47 \pm 0.012$ \\
\hline 3 & Kwalta Street & $206.6 \pm 11.5$ & $850 \pm 31.6$ & $1.65 \pm 0.017$ \\
\hline 4 & Kwarin Gogau & $292 \pm 8.6$ & $420 \pm 31.5$ & $1.17 \pm 0.01$ \\
\hline 5 & Samaru & $262.9 \pm 2.7$ & $574 \pm 51.3$ & $2.3 \pm 0.022$ \\
\hline 6 & Kwari Market & $198.7 \pm 1.2$ & $480 \pm 12.3$ & $0.428 \pm 0.013$ \\
\hline 7 & Yan Babura & $224.3 \pm 5.4$ & $400 \pm 23.1$ & $0.315 \pm 0.01$ \\
\hline 8 & Dingazimi Street & $424.8 \pm 3.9$ & $450 \pm 3.5$ & $1.58 \pm 0.014$ \\
\hline 9 & Salam Opp. Triump & $284.3 \pm 4.1$ & $706 \pm 13.1$ & $1.42 \pm 0.02$ \\
\hline 10 & Mutari Atamma Street & $290.4 \pm 8.4$ & $500 \pm 42.4$ & $0.601 \pm 0.016$ \\
\hline 11 & Triump Juma'at Mosque & $456.3 \pm 12.4$ & $400 \pm 22.8$ & $1.264 \pm 0.014$ \\
\hline 12 & Haido Islamiyya & $210.8 \pm 6.3$ & $360 \pm 11.9$ & $0.699 \pm 0.011$ \\
\hline 13 & Fagge Model primary School & $132.2 \pm 2.4$ & $560 \pm 17.7$ & $0.589 \pm 0.013$ \\
\hline 14 & Ammani inuwa Street & $160.4 \pm 5.3$ & $440 \pm 11.9$ & $1.26 \pm 0.02$ \\
\hline 15 & Alh. Mudi Street & $292.8 \pm 5.6$ & $460 \pm 14.7$ & $1.413 \pm 0.011$ \\
\hline 16 & Abba Gana Street & $300.3 \pm 11.6$ & $460 \pm 31.9$ & $0.554 \pm 0.01$ \\
\hline 17 & Dan Wawu Street & $404.5 \pm 4.9$ & $480 \pm 18.8$ & $1.74 \pm 0.013$ \\
\hline 18 & Galadima Road & $606 . \pm 13.45$ & $500 \pm 34.8$ & $3.34 \pm 0.01$ \\
\hline 19 & Abacha Street Sabon Gari & $466.6 \pm 13.21$ & $460 \pm 15.2$ & $0.02 \pm 0.014$ \\
\hline 20 & Fagge South & $488.1 \pm 0.32$ & $320 \pm 23.6$ & $0.885 \pm 0.011$ \\
\hline 21 & Niger Road & $482.3 \pm 0.56$ & $354 \pm 12.9$ & $0.821 \pm 0.02$ \\
\hline 22 & Singer Market S/Gari & $174.1 \pm 15.3$ & $454 \pm 19.5$ & $0.35 \pm 0.015$ \\
\hline 23 & Weather head S/Gari & $236.8 \pm 3.22$ & $353 \pm 24.1$ & $0.852 \pm 0.01$ \\
\hline 24 & Festing Road S/Gari & $202.9 \pm 0.35$ & $678 \pm 18.0$ & $1.98 \pm 0.013$ \\
\hline 25 & Abeokuta Road S/gari & $260.3 \pm 2.4$ & $464 \pm 11.9$ & $0.53 \pm 0.02$ \\
\hline 26 & Atiken Road S/Gari & $184.4 \pm 1.45$ & $597 \pm 16.6$ & $0.40 \pm 0.014$ \\
\hline 27 & Sani Giwa Road S/gari & $154.8 \pm 3.45$ & $546 \pm 11.5$ & $1.872 \pm 0.016$ \\
\hline 28 & Abedie Street S/Gari & $142.3 \pm 1.42$ & $471 \pm 0.00$ & $0.275 \pm 0.024$ \\
\hline 29 & Amire Road S/Gari & $152.4 \pm 0.94$ & $205 \pm 5.6$ & $0.432 \pm 0.027$ \\
\hline 30 & Sarkin Yaki Road S/Gari & $172.9 \pm 0.56$ & $489 \pm 32.9$ & $0.585 \pm 0.016$ \\
\hline
\end{tabular}


Table 4. Mean levels for Lead, Cadmium, and Chromium of the water samples

\begin{tabular}{|c|c|c|c|c|}
\hline $\mathrm{S} / \mathrm{N}$ & SAMPLING SITES & $\mathrm{Pb}\left(\mathrm{mgl}^{-1}\right)$ & $\mathrm{Cd}\left(\mathrm{mgl}^{-1}\right)$ & $\operatorname{Cr}\left(\mathrm{mgl}^{-1}\right)$ \\
\hline 1 & Garba A.D Street & $0.11 \pm 0.001$ & $\mathrm{ND} \pm 0.00$ & $0.02 \pm 0.014$ \\
\hline 2 & Titinbo Street & $0.13 \pm 0.012$ & $0.01 \pm 0.00$ & $0.11 \pm 0.007$ \\
\hline 3 & Kwalta Street & $0.02 \pm 0.000$ & $\mathrm{ND} \pm 0.00$ & $0.15 \pm 0.000$ \\
\hline 4 & Kwarin Gogau & $0.31 \pm 0.011$ & $0.03 \pm 0.01$ & $0.45 \pm 0.001$ \\
\hline 5 & Samaru fagge & $0.14 \pm 0.012$ & $\mathrm{ND} \pm 0.00$ & $0.12 \pm 0.002$ \\
\hline 6 & Kwari Market & $\mathrm{ND} \pm 0.000$ & $\mathrm{ND} \pm 0.00$ & $0.01 \pm 0.000$ \\
\hline 7 & Yan Babura & $0.14 \pm 0.060$ & $\mathrm{ND} \pm 0.00$ & $\mathrm{ND} \pm 0.000$ \\
\hline 8 & Dingazimi Street & $\mathrm{ND} \pm 0.000$ & $0.02 \pm 0.01$ & $0.03 \pm 0.011$ \\
\hline 9 & Salam Opp. Triump & $0.11 \pm 0.002$ & $\mathrm{ND} \pm 0.00$ & $0.01 \pm 0.000$ \\
\hline 10 & Mutari Atamma Street & $0.02 \pm 0.011$ & $\mathrm{ND} \pm 0.00$ & $0.11 \pm 0.000$ \\
\hline 11 & Triump Juma’at Mosque & $0.13 \pm 0.009$ & $0.01 \pm 0.00$ & $0.15 \pm 0.010$ \\
\hline 12 & Haido Islamiyya & $0.14 \pm 0.015$ & $\mathrm{ND} \pm 0.00$ & $\mathrm{ND} \pm 0.000$ \\
\hline 13 & Fagge Model primary Sch. & $\mathrm{ND} \pm 0.000$ & $\mathrm{ND} \pm 0.00$ & $0.01 \pm 0.012$ \\
\hline 14 & Ammani inuwa Street & $0.12 \pm 0.018$ & $\mathrm{ND} \pm 0.00$ & $\mathrm{ND} \pm 0.000$ \\
\hline 15 & Alh. Mudi Street & $0.18 \pm 0.002$ & $\mathrm{ND} \pm 0.00$ & $\mathrm{ND} \pm 0.000$ \\
\hline 16 & Abba Gana Street & $0.15 \pm 0.004$ & $\mathrm{ND} \pm 0.00$ & $0.01 \pm 0.012$ \\
\hline 17 & Dan Wawu Street & $\mathrm{ND} \pm 0.000$ & $\mathrm{ND} \pm 0.00$ & $0.12 \pm 0.011$ \\
\hline 18 & Galadima Road & $0.16 \pm 0.006$ & $\mathrm{ND} \pm 0.00$ & $0.14 \pm 0.010$ \\
\hline 19 & Abacha Line Sabon Gari & $0.19 \pm 0.020$ & $\mathrm{ND} \pm 0.00$ & $\mathrm{ND} \pm 0.000$ \\
\hline 20 & Fagge South & $0.10 \pm 0.017$ & $\mathrm{ND} \pm 0.00$ & $\mathrm{ND} \pm 0.000$ \\
\hline 21 & Niger Road & $0.11 \pm 0.014$ & $\mathrm{ND} \pm 0.00$ & $\mathrm{ND} \pm 0.000$ \\
\hline 22 & Singer Market S/Gari & $0.13 \pm 0.016$ & $\mathrm{ND} \pm 0.00$ & $0.01 \pm 0.000$ \\
\hline 23 & Weather head S/Gari & $0.12 \pm 0.022$ & $\mathrm{ND} \pm 0.00$ & $0.02 \pm 0.003$ \\
\hline 24 & Festing Road S/Gari & $\mathrm{ND} \pm 0.000$ & $0.02 \pm 000$ & $0.03 \pm 0.047$ \\
\hline 25 & Abeokuta Road S/gari & $0.02 \pm 0.014$ & $\mathrm{ND} \pm 0.00$ & $0.01 \pm 0.003$ \\
\hline 26 & Atiken Road S/Gari & $0.03 \pm 0.052$ & $0.15 \pm 0.01$ & $0.13 \pm 0.000$ \\
\hline 27 & Sani Giwa Road S/gari & $0.21 \pm 0.095$ & $\mathrm{ND} \pm 0.00$ & $\mathrm{ND} \pm 0.000$ \\
\hline 28 & Abedie Street S/Gari & $0.20 \pm 0.081$ & $\mathrm{ND} \pm 0.00$ & $0.01 \pm 0000$ \\
\hline 29 & Amire Road S/Gari & $0.10 \pm 0.032$ & $\mathrm{ND} \pm 0.00$ & $0.1 \pm 0.020$ \\
\hline 30 & Sarkin Yaki Road S/Gari & $0.11 \pm 0.022$ & $0.01 \pm 0.00$ & $0.2 \pm 0.004$ \\
\hline
\end{tabular}

\section{Discussion}

The Results of $\mathrm{pH}$ levels in the various water samples are presented in figure 2, from the result it can be seen that all the sampling sites had $\mathrm{pH}$ level falling with the W.H.O recommended range value of 6.5 - 8.5 [16] except in sampling site at weather head Sabon Gari in which the $\mathrm{pH}$ level was found to be 6.2 which is slightly below the recommended range set by WHO. This could be attributed to acid rain, industrial waste, mining, sewage, waste dumping through leaching into the soil which ultimately increase the soil acidity and consequently the $\mathrm{pH}$ is lowered as observed by [4].

For Conductivity, Measurements were conducted in the water samples and the results revealed that about $33.3 \%$ of the sampling sites had conductivity level above W.H.O maximum contaminant level of $1200 \mu_{\mathrm{scm}}^{-1}$ [16] as shown in Table 2. However, the high conductivity level at the sites mentioned could be linked to sewage materials, leaching of inorganic contaminants as observed by [5].

The turbidity level in all the sample sites determined showed that they are within the recommended levels of 5 NTU [16] as shown in (Table 3). Higher turbidity in water could be due to Suspended materials, bacteria, plankton and dissolved organic and inorganic substance and higher turbidity is associated with Surface water sources as observed by [10].

The hardness levels were also analyzed and presented in (Table 4). Based on classification of water conducted by [11] in terms of softness and hardness in the following order in terms of mg/l. 0-60 soft, 60 - 120 moderately soft, and 121 - 180 moderately hard and above 180 is hard. Thus, considering this classification, it can be deduced that almost all the water samples analyzed are hard, but safe for drinking and other domestic purposes. However, the hardness could be removed by simple boiling, addition of chemicals e.g washing soda, sodium hydroxide, and ion exchange method.

From the results presented in (Table 1) the highest Sodium concentration was recorded in Mutari Atamma Street with a Concentration of $11.2 \mathrm{mg} / \mathrm{l}$. Although it is generally agreed that that sodium is essential to human life, there is no agreement on its maximum daily requirement. However, it has been estimated that a total daily intake of $120-140 \mathrm{mg}$ will meet the daily needs of growing infants and young children and $50 \mathrm{mg}$ for adults [6].

For potassium the highest concentration of potassium was recorded in Abacha Street, Sabon Gari with average concentration of $6.7 \pm 0.24 \mathrm{mg} / \mathrm{l}$ as shown in (Table 1 ). Potassium concentration in water is generally very small, although excessive amounts may have a laxative effect; potassium chloride is used as a replacement for salt in water softeners [10].

The alkalinity levels were assessed in the water samples and presented in (Table 4) the results indicate that majority of the sampling sites have alkalinity levels above the WHO maximum contaminant levels of $500 \mathrm{mg} / \mathrm{l}$ [16]. The Alkalinity value in water provides an idea of natural mineral salts present in the water. The main species that contribute to alkalinity includes bicarbonates, hydroxides, phosphates and borates [14].

The total dissolved solid was also analyzed and it can be observed that water from all the sampling sites had total dissolved solid levels below WHO maximum contaminant levels of $1000 \mathrm{mg} / \mathrm{l}$ [15], this is shown in Table 4. The higher total dissolved solid reduce water clarity, which could contribute to the decrease in photosynthetic activities and might lead to an increase in water temperature as observed by [6]

\subsection{Heavy Metals}

The heavy metals analysed were $\mathrm{Pb}, \mathrm{Cd}$, and $\mathrm{Cr}$. From the results (Table 3 ) it can be seen that all the samples 
ware within the safe limit recommended by [16] except for lead in Kwarin Gogau which is higher than the maximum contaminant level of $0.01 \mathrm{mg} / \mathrm{l}$ [15]. This may originate from corrosion of brass fitting of certain types of submersible pumps used in ground water wells as reported by [4]. It could also be due to passage of River Jakara stream Channel through the area as shown in Fig. 1 from sewage and industrial waste, refuse which may include lead battery that could ultimately leach into the ground thereby contaminating the water.

However the heavy metals concentrations are in the order $\mathrm{Cr}>\mathrm{Pb}>\mathrm{Cd}$ respectively as shown in (Table 3 )

\section{Conclusion}

Physicochemical assessment of borehole water samples from Fagge L.G.A of Kano metropolis was carried out. Most of the physical parameters are within the W.H.O safe limit. The levels of heavy metals were also found to be within the recommended levels set by W.H.O with exception of lead $(\mathrm{Pb})$.

Similarly, the Results of the analysis indicated that most of the physical parameters are related to one another. This can be seen in the Table 2, Table 3, and Table 4 respectively which show that higher Conductivity is related to higher Total Dissolved Solids, Salinity, Sodium, Potassium and hardness which rise as a result of the presence of $\mathrm{Ca}^{2+}$ and $\mathrm{Mg}^{2+}$ ions respectively.

Also it is observed that Turbidity and Total Suspended Solid are also related to one another as the TSS level was high the Turbidity was also high.

Moreover, the heavy metals concentrations are also related to the proximity of the sampling Area with Contaminated area that is River Jakara which is believed to have contain a lot of contaminants (pollutants) such as sewage, industrial effluents, dumping refuse that may include car batteries (Lead accumulator) and some other environmental pollutants.

However, since some of the results indicate high levels above the Standard set by W.H.O safe limits, there is the tendency of high potential health hazards to the inhabitants of the areas that uses these water sources for drinking and other domestic purposes without treatment.

\section{Recommendations}

As the results indicated, some of the parameters analyzed showed higher concentration above the WHO contaminant level especially the sampling sites very closer to jakara River which is believed to be contaminated, the following steps may lower the concentration. Heating the water before used can remove the temporary hardness. Domestic and industrial waste should be properly disposed of recycled. Relevant agencies should make concerted effort to control, regulate and educate the community on indiscriminate waste disposal from domestic and industries within the study area and also further research should be carried out to assess the level of some other parameters, replacing home plumbing components made from brass. Some other techniques like phytoremediation can be introduced to reduce the levels of the heavy metal contamination.

The limitation of this research is that trivalent metals ions and bacteriological analysis was not conducted this can be done for further research work.

\section{References}

[1] Ademorati. M. A. (1996). Standard Methods for water and effluent analysis. Foludex Press Ltd, Ibadan. 1st ed. Pp 80-83.

[2] American public association (APHA) (1992). Standard Methods for Examination of Water and waste 18th ed. American Public health Association, Washing ton D.C

[3] DeZuane, J. (1997). Handbook of Drinking Water Quality (2nd ed.). John Wiley and Sons. ISBN 0-471-28789-X.

[4] FAO/WHO, (1997). Expert committee food additives would health organization, Geneva. WHO Technical Report series (FAO) Rome 1 (2) 20-26.

[5] Harison, R.M. (1992). Understanding out Environmental Chemistry And Pollution. Cambridge University press 2nd ed. Pp 46-49.

[6] National Research Council of Canada NRCC (2011). Effect of Sodium And Potassium in the Canadian Environment. NO. 150154. Associate Committee on Scientific Criteria for Environmental Quality Otttawa.

[7] Okonko, I.O. Adejuye, O.D. and Oogunosi, T.A. (2007). Physicochemical Analysis of Different water Samples used for drinking Water Purpose in Abeokuta and Ojota Lagos. Nigeria African Journal of BioTechnology 70 (5): 617-621.

[8] Pink, D. H. (2006). Investing in tomorrow's liquid gold". yahoo. west, larry "world water day: a billion people worldwide lack safe drinking water". about.

[9] Post Offices- with map of LGA". NIPOST. Retrieved 2009-10-20.

[10] Reza, J. and Gordeep. S. (2009). Pre and Post Monsoon Variation of heavy Metals Concentration of Ground Water Of Angul Talcher Region of Orisse, India Natural and Science 7(6). 52-56.

[11] Roxanne J. and Tom S. (2012). Driving Water quality testing and interpreting your Results Revised Ed.

[12] Sachchida, Nand, Singhi, Gaurav, Srivastav and Arunbhat (2011). Department of Chemistry S.G.G. (P.G.) College, Dobhi, Jaunpur 222149 (India) Department of Biotechnology G.B. Pantt Engineering College Gurdahuri, Pauri Garhwal, (India).

[13] Tyson, A. and Harrison, K. (1992). Water Quality for private water system. Geogea Co-operative Extension Service University of Geogia, Athens G.A Seminar paper Presentation University of Geogia.

[14] United States Geological Survey, Denver, C.O. (USGS) (1998). Ground Water and Surface Water: A Single Resource." Circular 1139.

[15] Wetzel, R.G. (2001). Limnology; lake and River Ecosystem 3rd ed. Academic Press New York 1006 pp.

[16] WHO, (1999). Guidelines for drinking quality water WHO, Geneva pp(160-220).

[17] WHO, (2005). Guidelines for drinking water quality criteria and other supporting information. 2nd ed. Geneve, Pp 5-7. 